\title{
Perencanaan Persediaan Bahan Baku Rajungan Menggunakan Metode MRP (Material Requirement Planning) (Studi Kasus : UD. Gerald Unedo)
}

\author{
Eka Wahyuni Fajriyah'1, Moh. Fuad Fauzul M.ㄹ, Askur Rahman ${ }^{3}$ \\ ${ }^{1,2,3}$ Fakultas Pertanian, Universitas Trunojoyo Madura \\ 1ekawahyunifajariyah@gmail.com
}

\begin{abstract}
ABSTRAK
Pengadaan bahan baku sering menjadi permasalahan dalam suatu industri. Pengadaan bahan baku yang baik dapat memperlancar jalannya suatu proses produksi sehingga kebutuhan dapat terpenuhi tepat waktu dan meminimalisasi biaya pengadaan. UD. Gerald Unedo yang terletak di Desa Sabiyan Bangkalan merupakan perusahaan yang bergerak di industri rajungan berproduksi sebagai pengulitan Rajungan. Pengadaan bahan baku metode perusahaan dilakukan berdasarkan apa yang biasa dilakukansebelumnya oleh perusahaan yaitu perusahaan akan memproduksi berapapun bahan baku yang tersedia pada suplier.Hasil yang telah dilakukan dengan metode MRP teknik Lot For Lot didapatkan biaya pemesanan sebesar Rp. 247. 470. 417 dan biaya penyimpanan sebesar Rp. 256. 700. 806 penghematan sebesar 44 \% lebih hemat dibandingkan dengan metode perusahan.
\end{abstract}

\section{Kata kunci : Persediaan, Pengadaan, Pemesanan, Penyimpanan, Lot For Lot, UD. Gerald Unedo}

\begin{abstract}
The supply of raw materials is often a problem in an industry. Procurement of good raw materials can facilitate the running of a production process so that needs can be met on time and minimize procurement costs. UD. Gerald Unedo located in Sabiyan Bangkalan Village is a company engaged in the crab industry produces as a difficulty of Rajungan. Procurement of raw materials company method is done based on what used to be done before by the company that the company will produce whatever the raw materials available on suplier.a result has been done with the method of MRP techniques Lot For Lot method a obtained booking is fee of Rp. 247. 470.417 and the storage fee of Rp. 256. 700. 806 savings of $44 \%$ than efficient more the method of the company.
\end{abstract}

Keywords: Inventory, Procurement, Booking, Storage, Lot For Lot, UD. Gerald Unedo 


\section{PENDAHULUAN}

Setiap perusahaan yang bergerak dalam bidang industri pangan baik itu perusahaan besar, perusahaan menengah, maupun perusahaan kecil sudah tentu memiliki teknik pengendalian jumlah persediaan bahan baku yang bermacam-macam. Hal ini dikarenakan setiap perusahaan pasti memiliki cara tersendiri dalam mengatasi permasalahan pengendalian jumlah persediaan bahan baku. Jumlah persediaan bahan baku yang tinggi akan menyebabkan tingginya biaya penyimpanan dan investasi yang diperlukan. Apabila jumlah persediaan bahan baku tidak mencukupi maka proses produksi akan terhambat.

UD Gerald Unedo terletak di Desa Sabiyan Bangkalan. Perusahaan ini bergerak di industri rajungan, berproduksi sebagai pengulitan rajungan. Masalah yang terjadi di UD. Gerald Unedo ini mengenai persediaan bahan baku yang kurang terkontrol. Hal tersebut dikarenakan pemesanan bahan baku yang terlalu banyak sehingga perusahaan mengeluarkan biaya penyimpanan. Penyediaan bahan baku dalam perusahaan tidak dilakukan dengan perencanaan atau sistem yang pasti dikarenakan tingkat permintaan produk yang fluktuatif.

Batasan masalah yang digunakan dalam penelitian ini yaitu perhitungan bahan baku dilakukan pada bahan baku rajungan, bahan baku yang dianalisis adalah bahan baku yang paling banyak kebutuhannya yaitu rajungan kebutuhan bersih rajungan sama dengan kebutuhan kotor bahan baku rajungan, teknik MRP (Material Requirement Planning) yang digunakan yaitu Lot For Lot.

Berdasarkan latar belakang diatas, maka dapat dirumuskan
Bagaimana perbandingan biaya persediaan bahan baku rajungan menggunakan metode perusahaan dengan metode Material Requirement Planning (MRP) teknnik Lot For Lot di UD. Gerald Unedo, apakah penerapan metode MRP (Material Requirement Planning) pada industri UD Gerald Unedo dalam merencanakan persediaan bahan baku produk rajungan berjalan dengan efektif dan efisien. Tujuan yang ingin dicapai dalam penelitian ini adalah untuk mengetahui perbandingan biaya persediaan bahan baku rajungan menggunakan metode perusahaan dengan metode MRP (Material Requirement Planning) teknik Lot For Lot di UD. Gerald Unedo. Untuk mengetahui penerapan metode MRP (Material Requirement Planning) pada industri UD. Gerald Unedo dalam merencanakan persediaan bahan baku produk rajungan dapat berjalan secara efektif dan afisien.

Perencanaan kebutuhan material dilakukan dengan metode MRP yang penerapanya diawali dengan melakukan peramalan akan jumlah permintaan/produksi untuk waktu yang akan datang, dengan mengetahui harga bahan penyusunan, data kebutuhan material, struktur produk, dan biaya untuk persediaan material, kemudian dilakukan perbandingan biaya perencanaan persediaan dengan menggunakan metode Lot For Lot (LFL), Fixed Period Requirement (FPR), Fixed Order Quantity (FOQ) (Astana 2007).

Material Requirement Planning (MRP) adalah prosedur logis, antara keputusan dan dan teknik pencatatan terkomputerisasi yang dirancang untuk menterjemahkan jadwal Induk Produksi atau MPS (Master Production Schedulling) menjadi kebutuhan bersih atau NR (Net 
Requirement) untuk semua item. Sestem MRP dikembangkan untuk membantu perusahaan manufaktur mengatasi kebutuhan akan item-item dependent secara lebih baik dan efisien. Selain itu, sistem MRP didesain untuk melepaskan pesananpesanan dalam produksi dan pembelian untuk mengatur aliran bahan baku dan persediaan dalam proses sehingga sesuai dengan jadwal produksi untuk produk akhir. $\mathrm{Hal}$ ini memungkinkan perusahaan memelihara tingkat minimum dari item-item yang kebutuhanya dependent, tetapi tetap dapat menjamin terpenuhinya jadwal produksi untuk produk akhirnya. Sistem MRP juga dikenal sebagai perencanaan kebutuhan berdasarkan tahapan waktu time phases requirement planning (Nasution dan Prasetyawan 2008).

Pemesanan pada teknik Lot For Lot dilakukan sebesar kebutuhan kotor dikurangi dengan persediaan yang ada ditangan dan diharapkan pesanan datang saat barang tersebut tepat diperlukan. Teknik ini berusaha menghilangkan biaya penyimpanan persediaan, perusahaan memesan tepat sebesar yang dibutuhkan tanpa persediaan pengaman dan tanpa antisipasi atas pesanan lebih lanjut. Periode berikutnya setelah persediaan awal dihabiskan tidak terdapat persediaan yang ada di tangan, sehingga kebutuhan kotor adalah sama dengan kebutuhan bersih yang akan dipesan dengan harapan akan diterima tepat pada waktunya (Shaliha 2012).

\section{METODE PENELITIAN}

Penelitian dilaksanakan di UD. Gerald Unedo yang terletak di Desa Sabiyan Bangkalan. Penelitian ini dimulai pada bulan Oktober 2016 sampai dengan bulan Maret 2017 dan data yang digunakan dalam perencanaan yaitu 2 tahun pada periode Januari 2015 sampai bulan Desember 2016.

\section{HASIL DAN PEMBAHASAN}

Perusahaan PT. Gerald Unedo berdiri selama 10 tahun yang didirikan oleh Bapak Musa Pangabean. UD. Gerald Unedo terletak di Desa Sabiyan Bangkalan yang bergerak dibidang pengulitan rajungan. Awalnya perusahaan ini di rintis karna adanya keinginan dari pemilik untuk meningkatkan ekonomi masyarakat sekitar dengan menambah lapangan pekerjaan di desa tersebut. Awalnya Bapak Musa bekerja disebuah perusahaan perikanan di Medan kemudian beliau mengembangkan skill nya dengan membuka usaha sendiri di Desa Sabiyan dengan melihat peluang di desa tersebut.

\section{Sistem Pengendalian Persediaan}

Bahan Baku di UD. Gerald UnedoPengendalian tingkat persediaan bahan baku rajungan perusahaan dilakukan berdasarkan apa yang telah menjadi kebiasaan dan menyesuaikan dengan kapasitas produksi masakan saat itu. Selama ini untuk menjaga ketersediaan rajungan digudang UD. Gerald Unedo melakukan pembelian rajungan berdasarkan pada suplier. Rata-rata pemesanan rajungan dilakukan setiap hari dengan kuantitas sebesar $900 \mathrm{Kg}-3$ ton.

\section{Sistem Persediaan dan Pembelian Bahan Baku Perusahaan}

Komponen yang digunakan untuk perhitungan biaya persediaan dan pembelian rajungan perusahaan. Berdasarkan Tabel 1 total persediaan rata-rata di gudang sebesar 2.523.976 Kg. Persediaan rata-rata merupakan persediaan rajungan 
Tabel 2. Komponen Biaya Pemesanan Per Pesan rajungan UD. Gerald Unedo Periode Januari 2015 - Desember 2016

\begin{tabular}{lcc}
\hline Jenis Biaya & Rp/pesan & Persentase (\%) \\
\hline Biaya Transport & 275.000 & 65 \\
Biaya Bongkar Muat & 150.000 & 35 \\
\hline Total & 425.000 & 100 \\
\hline
\end{tabular}

Sumber : Olahan Data, $2015-2016$

Tabel 3. Biaya Penyimpanan Rajungan Per Kg Rajungan UD. Gerald Unedo Periode Januari 2015 - Desember 2016

\begin{tabular}{lcccc}
\hline \multirow{2}{*}{$\begin{array}{l}\text { Komponen } \\
\text { biaya }\end{array}$} & \multicolumn{4}{c}{ Biaya penyimpanan rajungan } \\
\cline { 2 - 5 } & $\begin{array}{c}\text { Nilai } \\
(\mathrm{Rp} / \mathrm{Kg} / \mathrm{tahun})\end{array}$ & $\begin{array}{c}\text { Nilai } \\
(\mathrm{Rp} / \mathrm{Kg} / \mathrm{bulan})\end{array}$ & $\begin{array}{c}\text { Nilai } \\
(\mathrm{Rp} / \mathrm{Kg} / \mathrm{ming} \mathrm{nu})\end{array}$ & $\begin{array}{c}\text { Nilai } \\
(\mathrm{Rp} / \mathrm{Kg} / \mathrm{Hari})\end{array}$ \\
\hline Es Batu & 2.160 .000 & 90.000 & 21.000 & 3.000 \\
\hline
\end{tabular}

Sumber : Olahan Data, $2015-2016$

yang ada digudang selama periode Januari 2015 - Desember 2016. Persediaan rata-rata perbulan diperoleh dari rata-rata persediaan awal dan persediaan akhir untuk setiap bulannya. Sementara total pembelian rajungan pada periode tersebut sebesar $1.050 .142 \mathrm{Kg}$ dengan total frekuensi pembelian sebanyak 713 kali. Semakin besar kuantitas pembelian, frekuensi dan persediaan rajungan di gudang, akan meningkatkan biaya persediaan dan biaya pembelian bahan baku rajungan bagi perusahaan.

Biaya transportasi merupakan biaya yang dikeluarkan oleh perusahaan untuk melakukan pemesanan rajungan sebesar $\mathrm{Rp}$. 275.000 dan biaya bongkar muat yaitu biaya yang dikeluarkan perusahaan untuk upah pekerja yang menurunkan dan mengangkut bahan baku kegudang/ruang produksi sebesar Rp. 150.000 sehingga didapatkan hasil total biaya sebesar Rp. 425.000.

Biaya penyimpanan yang dikeluarkan perusahaan dengan adanya persediaan rajungan digudang bahan baku sebesar $\mathrm{Rp}$.
2.160.000 /Kg per-2 tahun, untuk biaya penyimpanan perbulan sebesar Rp. 90.000,- untuk biaya penyimpanan perminggu sebesar Rp. 21.000 dengan biaya penyimpanan per hari sebesar Rp 3.000 perkilo gram.

\section{Biaya Persediaan}

Biaya persediaan merupakan biaya-biaya yang dikeluarkan akibat adanya persediaan itu sendiri. Biaya persediaan terdiri dari biaya variabel dan biaya tetap. Biaya variabel antara lain biaya pemesanan (Ordering Cost) dan biaya penyimpanan (Storage Cost). Sementara biaya tetap yakni harga dari rajungan. Pada UD. Gerald Unedo biaya persediaan yang dimasukkan antara lain biaya pemesanan dan biaya peyimpanan serta biaya pembelian periode Januari 2015 - Desember 2016. Perhitungan biaya persediaan bahan baku rajungan UD. Gerald Unedo dapat dilihat pada Tabel 4.

Total biaya persediaan merupakan jumlah dari biaya pemesanan dan biaya penyimpanan. Dari tabel diatas total biaya 
Tabel 4. Biaya Persediaan Bahan Baku rajungan Periode Januari 2015 - Desember 2016 Menggunakan Kondisi Aktual Perusahaan.

\begin{tabular}{|c|c|c|c|c|c|c|}
\hline \multicolumn{3}{|c|}{ Biaya pemesanan } & \multicolumn{3}{|c|}{ Biaya penyimpanan } & \multirow[b]{2}{*}{$\begin{array}{l}\text { Biaya total } \\
\text { persediaan }\end{array}$} \\
\hline Rp/pesan & Frek & Total (Rp) & $\mathrm{Rp} / \mathrm{Kg}$ & $\begin{array}{c}\text { Jumlah } \\
\text { persediaa } \\
\mathbf{n} \\
\text { rata-rata } \\
\end{array}$ & Total & \\
\hline 440.000 & 713 & 313.720 .000 & 3.000 & $\begin{array}{c}2.523 .97 \\
6\end{array}$ & $\begin{array}{c}7.571 .928 .8 \\
00\end{array}$ & 7.885 .648 .000 \\
\hline
\end{tabular}

Sumber : Olahan Data (2015 - 2016)

Tabel 5. Perbandingan Frekuensi, Kuantitas Pembelian, Persediaan Digudang, Biaya Penyimpanan, Biaya Persediaan dan Biaya Pembelian Rajungan UD. Gerald Unedo Periode Januari 2015 - Desember 2016

\begin{tabular}{lcc}
\hline \multicolumn{1}{c}{ Uraian } & Perusahaan & LFL \\
\hline Frekuensi (kali) & 713 & 713 \\
Kuantitas pembelian (Kg) & 1.050 .142 & 1.050 .142 \\
Kuantitas persediaan digudang & 2.523 .976 & 85.567 \\
$($ Kg) & 313.720 .000 & 247.470 .417 \\
Biaya pemesanan (Rp) & 7.571 .928 .000 & 256.700 .806 \\
Biaya penyimpanan (Rp) & 7.885 .648 .000 & 4.395 .751 .949 \\
Biaya persediaan (Rp) & 42.005 .680 .000 & 42.005 .680 .000 \\
Biaya pembelian (Rp) & &
\end{tabular}

persediaan yang dikeluarkan oleh UD. Gerald Unedo sebesar Rp. 7.885.648.000 per- 2 tahun. Masingmasing terdiri dari biaya yang dikeluarkan untuk pemesanan rajungan periode Januari 2015 Desember 2016 sebesar Rp. 313.720.000,- dan biaya yang keluar akibat persediaan digudang berupa biaya penyimpanan sebesar $\mathrm{Rp}$. 7.571.928.800,- per- 2 tahun. Dari tabel diatas dapat diketahui bahwa biaya penyimpanan rajungan lebih besar dari biaya pemesanannya. Sehingga perlu dilakukan penurunan kuantitas pembelian rajungan tanpa mengganggu kelancaran proses produksi. Sehingga biaya pengeluaran persediaan bahan baku rajungan dapat ditekan.

\section{Analisis Perbandingan Metode Pengendalian Persediaan}

Berdasarkan perhitungan metode pengendalian persediaan teknik perusahaan dan teknik Lot For Lot selama periode Januari 2015 Desember 2016 dapat dilakukan perbandingan antar metode Lot For Lot dan metode yang digunakan oleh perusahaan. Ringkasan perhitungan disajikan pada tabel 5. Dari hasil perhitungan diketahui pengendalian persediaan dengan metode MRP menghasilkan biaya persediaan lebih rendah dari teknik yang dilakukan oleh UD. Gerald Unedo.

Metode MRP teknik Lot For Lot memungkinkan perusahaan melakukan penghematan biaya persediaan rajungan. Jumlah 
pemesanan rajungan sebesar kebutuhan bersih. Sehingga biaya yang ditanggung perusahaan terhadap adanya rajungan yang ada digudang (biaya penyimpanan) lebih kecil dari teknik perusahaan. Hasil analisis dengan teknik Lot For Lot mampu memberikan alternatif penghematan biaya persediaan perusahaan. Penghematan dengan teknik Lot For Lot terhadap biaya persediaan rajungan mencapai $\mathrm{Rp}$. 3.489.896.051,- (44\%).

\section{SIMPULAN}

$\begin{array}{cc}\text { Metode } & \text { perusahan } \\ \text { melakukan frekuensi } & \text { pembelian }\end{array}$

\section{DAFTAR PUSTAKA}

Assauri S. 2016. Manajemen Operasi Produksi. Jakarta: Fakultas Ekonomi. Universitas Indonesia.

Assauri, Sofjan. 2008. Manajemen Produksi dan Operasi. Lembaga Penerbit Jakarta: Fakultas Ekonomi UniversitasIndonesia.

Astana, NY. 2007. Perencanaan persediaan bahan baku berdasarkan metode material requirement planning (MRP). Jurnal IImiah Teknik Sipil Vol. 11 No. 02 : 184-194.

Aulia, N. 2010. Penerapan Metode Material Requirement Planning pada Industri Kecil Tenun Tengku Agung Pekanbaru. Skripsi. Bogor: Departemen Manajemen Fakultas Ekonomi dan Manajemen Institut Pertanian Bogor.

Bahagia S. 2006. Sistem Inventori. Bandung: ITB Bandung.

Baroto, Teguh. 2002. Perencanaan dan Pengendalian Produksi. Jakarta : Ghalia Indonesia.

Emawati, MN. 2010. Perencanaan Kebutuhan Bahan Baku pada bahan baku rajungan sebesar 713 kali pemesanan dengan biaya pemesanan sebesar Rp. 313.720.000 dan metode Lot For Lot melakukan frekuensi sebanyak 713 kali pemesanan dengan biaya sebesar Rp. 247.470.417 memberikan penghematan sebesar Rp. 3.279.861.551

Biaya persediaan bahan baku bulan Januari 2017 - Desember 2018 metode LFL memberikan Penghematan biaya Sebesar Rp. 3.489.896.051 dengan presentase 44 $\%$ lebih hemat di bandingkan dengan metode perusahaan.

Proses Produksi pada Buku BSE (Buku Sekolah Elektronik) IPS dengan Metode Material Requirement Planning (MRP) pada PT. Nyata Grafika Media. Manajemen Industri. Skripsi. Fakultas Ekonomi. Universitas Sebelas Maret Surakarta.

Fahrudin, V. 2009. Penerapan Material Requirement Planning pada Pengendalian Persediaan Bahan Baku dan Pengaruhnya Terhadap Biaya Persediaan. Skripsi. Surakarta: Fakultas Ekonomi Universitas Sebelas Maret.

Hendra, K. 2004. Manajemen Produksi. Yogyakarta: ANDI.

Ismiwarti. 2005. Pemanfaatan Cangkang Rajungan (Portunus sp) Sebagai Flafor. Skripsi. Bogor: Fakultas Perikanan dan IImu Kelautan Institut Pertanian Bogor.

Jonnius dan Ali, A. 2011. Analisis Forecasting Penjualan Produk Perusahaan. Fakultas Syariah dan IImu Hukum UIN Suska Riau 
Kusuma, K. 2009. Perencanaan dan Pengendalian Produksi. Edisi 4. Yogyakarta: Penerbit Andi. Nasution AH, Prasetyawan Y . 2008. Perencanaan dan Pengendalian Produksi. Cetakan pertama. Yogyakarta: Graha Ilmu.

Nurani, G. 2013. Perhitungan pengadaan bahan baku roti tawar dengan metode material requirement planning (MRP). Skripsi. Fakultas pertanian. Bangkalan: Universitas Trunojoyo Madura.

Nurhasanah, N. 2005. Perencanaan Pengendalian Produksi dan Persediaan Industri Pasta PT "xyz". Jurnal Teknik Industri. Vol.6 No.2 2005: 109-133

Maharani, MH. 2015. Perbandingan Sistem Economic Order Quantity dan Just In Time pada Pengendalian Persediaan Bahan Baku. Skripsi. Diponegoro: Fakultas Ekonomika dan Bisnis Universitas Diponegoro.

Purwati, S. 2008. Analisis Peranan MRP (Material Requirement Planning) Untuk Produk Kursi Benelux Pada CV Aksen Rattan Cirebon. Skripsi. Fakultas Bisnis dan Manajemen, Universitas Widyatama.

Render, B \& Heizer, J. 2005. Manajemen Operasi (Terjemahan). Jakarta: Salemba Empat.

Robiyanto,CB. 2013. Analisis persediaan bahan baku tebu pada barik gula pandji. Bali: Universitas Udayana. EJurnal Agribisnis dan Agrowisata. Vol. 02. No. 01 : 23-31.
Soegihardjo, M. 2000. Studi Kasus Perbandingan antara 'Lot For Lot' dan 'Economic Order Quantity' sebagai Metode Perencanaan Penyediaan Bahan Baku. Universitas Krosten Petra. Jurnal Teknik Mesin. Vol. 1 No. 2 : 151-156.

Taryana, N. 2008. Analisis pengendalian persediaan bahan baku pada produk sepatu dengan pendekatan teknik lot sizing dalam mendukung sistem MRP. Skripsi. Fakultas Teknologi Pertanian Institut Pertanian Bogor.

Widodo, S . 2017. Analisis Metode Single Moving Average dan Exponential Smoothing Dalam Peramalan Permintaan Senapan Angin (Studi Kasus : UD. HAFARA). Skripsi. Program Studi Teknik Informatika Fakultas Teknik Universitas Nusantara PGRI Kediri.

Wilis, F (2002). Analisis Pengendalian Persediaan Bahan Baku Produksi Pisang Sale di CV. Kiniko Enterprise. Sumatera Barat. Skripsi. Jurusan Ilmu-IImu Sosial Ekonomi Pertanian Fakultas Pertanian Institut Pertania Bogor.

Wohos, IP \& Mandagi,D. R.. 2014. Pengendalian Material Proyek dengan Metode Material Requirement Planning pada Pembangunan Star Square Manado. Jurnal Tekno Sipil. Volume 12. No. 06.

Yamit, Z. 2003. Manajemen Produksi dan Operasi. Edisi Kedua. Yogyakarta: EKONISIA 